\title{
Gender Equality and Women Business of Framework 5Ms in Kazakhstan: Analysis and Basic Directions
}

\author{
Zaira T. SATPAYEVA*, Anel A. KIREYEVA**, Gaukhar KENZHEGULOVA ${ }^{* * *}$, Dinara YERMEKBAYEVA**** \\ Received: January 11, 2019 Revised: February 02, 2020 Accepted: February 06, 2020.
}

\begin{abstract}
This study aims to analyze of existing concepts of female entrepreneurship, evaluation of women's entrepreneurship in Kazakhstan and development of recommendations for its development in the country. This paper begins by reviewing research on female entrepreneurship. In this research, authors proposed the methodological tools based on systematic approach using economic and statistic methods and 5Ms concept. Analysis algorithm consists of four stages: evaluation of women entrepreneurship scale and business directions, analysis of employment in women's enterprises and business environment in Kazakhstan. The main limitation of this study was the lack of some gender-related indicators on the development of entrepreneurship. Further, the obtained results showed strong and weak points of female entrepreneurship in Kazakhstan. According to the results, there has observed increase in contribution of women in social-economic development of the republic, women's entrepreneurial activity is increasing, and the number of enterprises headed by them is growing. However, the growth of female entrepreneurship occurs while maintaining their insignificance in terms of turnover and number of employees. There is a pronounced industry specificity of female entrepreneurship: the service sector. In accordance with this, there were identified priority areas and there were developed recommendations for the development of female entrepreneurship in Kazakhstan.
\end{abstract}

Keywords : Gender, Gender Economics, Gender Policy, Business, Female Entrepreneurship, Kazakhstan

JEL Classification Code: J16, J22, J31.

\section{Introduction}

Many scientists emphasis the increasing impact of economic potential of women and their contribution in social and economic development of the country (ABD, 2013). Expansion of women's economic empowerment is central to gender equality achievement, fight against

*First Author. Senior Researcher, Institute of Economics of the Ministry of Education and Science of the Republic of Kazakhstan, Kazakhstan. Email: szt_kz@mail.ru

${ }^{* *}$ Corresponding Author. Chief Researcher, Institute of Economics of the Ministry of Education and Science of the Republic of Kazakhstan [Postal Address: 29 Kurmangazy Street, Almaty, 050010, Kazakhstan] Tel: +7-701-690-0466

Email: anele19@mail.ru

***PhD Student, Narxoz University, Kazakhstan.

Email: gaukhar.kenzhegulova@gmail.com

${ }^{* * * *}$ Head of Department, University of International Business, Kazakhstan. Email: ermekbaevad@mail.ru

(c) Copyright: The Author(s)

This is an Open Access article distributed under the terms of the Creative Commons Attribution NonCommercial License (https://creativecommons.org/licenses/by-nc/4.0/) which permits unrestricted noncommercial use, distribution, and reproduction in any medium, provided the original work is properly cited. poverty among women and the solution of women unemployment. Development of women economic rights and possibilities does not eliminate gender inequality, but it holds much significance. Generally, empowerment of women and has been explored from the standpoint of such indicators as education, capability of women to render a decision, social gender equality, social support, working load and hours autonomy and control over income and other resources and funds. The concept of empowerment centers around three interconnected dimensions: resources, actions and achievements (Gupta, Pingali, \& PinstrupAndersen, 2017).

Organization for Economic Cooperation and Development has classified women empowerment issues into three "E": education, employment and entrepreneurship (OECD, 2014). Staging directions of strategic objective of Kazakhstan becoming one of the 30 most developed countries in the world, the indicators of OECD countries have become fundamental to the development of the republic. For this reason, ensuring of gender equality in education, employment and in 
entrepreneurship activity has become of urgent matter for Kazakhstan. Today Kazakhstan is pursuing a positive policy on ensuring gender equality in the country, including entrepreneurship field (Kireyeva \& Satybaldin, 2019). For improvement of women entrepreneurship in the republic and determining of priority directions for further development a deep study of all aspects of women business is necessary.

An objective study of the processes of formation and functioning of enterprises headed by women will allow us to substantiate accurately the key areas in improving the efficiency of business in the country. This has contributed to the creation of a certain theoretical base of the research. However, there are issues that remain a constant subject of discussion, in particular, the definition of women's entrepreneurship, the definition of guidelines for its analysis and evaluation. Therefore, a significant number of scientific developments in Kazakhstan on female entrepreneurship are reduced to description of the results of sociological studies. At the same time, studies that address theoretical and methodological issues, as well as the statistical measurement of female entrepreneurship, algorithms and methods for its analysis are still poorly developed. Notwithstanding in many studies there have been provided constructive study of individual aspects of female entrepreneurship, however there has not been done a holistic and consistent review. Thus far, the degree of the research of current field in the context of Kazakhstan is extremely low.

The purpose of this research is to analyze of existing concepts of female entrepreneurship, to evaluate female entrepreneurship activities in Kazakhstan, as well as elaboration of recommendations on women entrepreneurship development within a country. This paper is among the scientific works, which identify factors of women entrepreneurship development and analyze current state and development of female entrepreneurship. Therefore, in accordance with the goal we have identified the following tasks:

Firstly, to explore existing concepts of female entrepreneurship.

Secondly, to analyze female entrepreneurship activity in Kazakhstan.

Thirdly, to determine priority guidelines and develop recommendations on female entrepreneurship development in Kazakhstan.

The work is framed in the following way. The first section includes literature review of current foreign literature on women entrepreneurship. The second section introduces methodology and data used in this paper. The third section presents the results of the research. The fourth section contains conclusion and proposals for future research on this topic in Kazakhstan.

\section{Literature Review}

\subsection{Theoretical Background on the Women Entrepreneurship}

In the context of the formation of the modern type of social relations, the role of women in society is changing in a certain way, and her social functions are defined differently. Women are involved in different new kinds of activities including entrepreneurship. Gender aspect of modern economic affairs has attained a special female meaning. In the market economy conditions, women more actively take part in the system of entrepreneurial relations, form typically "gender niches" of modern economic activity of the population. Therefore, the study of the formation and modern development of female entrepreneurship has not only scientific, but also practical and applied meaning.

Women's entrepreneurship, as a form of women's economic rights and opportunities, has been the subject of research in the last quarter of the 20th century. The emergence of research on women's entrepreneurship in that period was a response to the results of the "quiet revolution on the global scale" (Parker, 2010). Opportunities for women in entrepreneurship activity and female entrepreneurship are the subject of study of many studies of foreign and local authors of different subjects, including practitioners of government agencies and international organizations (Andriuta \& Kartašova, 2013).

The influence of women in business has taken attention of many scientists. However, some experts believe that entrepreneurship does not have a special tender dimension, and that a business can be female or male (Fayolle \& Kyrö, 2008). Initial studies in entrepreneurship suggested that male and female entrepreneurs were generally the same, and there was little need for a separate study (Yordanova \& Tarrazon, 2010). While modern research raises the importance of women entrepreneurship and its development opportunities. In particular, many scientific works have been devoted to women's business and the experience of women, where there has been an increase in interest in this topic and a significant increase in research on women's entrepreneurship (Carlsson, Braunerhjelm, McKelvey, Olofsson, Persson, \& Ylinenpaa, 2013; Jennings \& Brush, 2013; Yadav \& Unni, 2016).

During recent years, there have appeared several research works dedicated directly to either women entrepreneurship, or affecting some of its aspects, including career, employment and labor market (Ács, Szerb, \& Lloyd, 2017; Estrin \& Mickiewicz, 2011; Kireyeva \& Satybaldin, 2019). Researches focused on the study of female entrepreneurship and women entrepreneurs differ in the level of study of the problem: micro (at the 
individual level), meso (at the firm level) and macro (at the country, region, and culture) level (Chandrashekhar, 2011; Adachi \& Hisada, 2017; Xie \& Lv, 2018; Verheul et al., 2006). They addressed various issues, including entrepreneurial orientation, self-efficacy, motivation, decision-making models, growth strategies, financing, social capital, productivity and growth, resources and limitations in a female startup. It should be noted that the phenomenon of women entrepreneurship is inextricably linked and is based on the phenomenon of entrepreneurship in general (Aidis \& Weeks, 2016). In addition, the females, it was observed that they placed more emphasis on the relational factors between themselves and the service that was provided (Kim \& Yang, 2020).

Scientific views in the field of women's business were developed in the studies of classics and modern authorities of economic and sociological science (Ebner, 2005; Gupta et al., 2016). In the works of these authors, here have been analyzed general patterns of entrepreneurship development, there have been studied the characteristic features of business evolution, there have been comprehended some of the latest trends in the development of entrepreneurial relations. Recognizing the significant contribution of the work of social science authors to the study of the phenomenon of entrepreneurship, it should be noted that they have a more general methodological significance, not always adequately reflecting various aspects of the development of entrepreneurship in the conditions of transformation of society, and practically do not touch upon important and specifically complex problems of modern business in digitalization (Poggesi et al., 2015; Kireyeva et. al., 2018; Dos Santos et al., 2019).

Principally, in the process of organizing and doing business there interact both genders regardless of whether what membership is dominating or who is the direct entrepreneur (Jennings \& Brush, 2013). Assuming that female entrepreneurship is an individual development of socio economic advancement.

\subsection{Concept that Affecting for Female Entrepreneurship}

The theoretical foundations for the study of gender and entrepreneurship are laid in feminist theory. Feminist theories recognize that submission, inequality or oppression of women is unethical and that women deserve equal political, economic and legal rights. Evolving from feminist theories, the deprivation argument says that public views deprive women of education, industry experience, networking, and access to capital. Deprivation of these opportunities may affect the success of women in business (Sospeter et al., 2014). The main objective of feminist research and politics is to achieve a state of women similar to that of men by eliminating explicit or systemic forms of discrimination, mainly directed against women (Okafor \& Amalu, 2010).

There are radical, liberal, social feminist approaches. Representatives of the first approach associate innate biological differences with the existence of patriarchy and female oppression. The reproductive roles and experiences of women and men evoke various traits of women and men. The second approach assumes that both sexes are equally rational. However, society remains structured around patriarchal norms, which puts women at a disadvantage in order to compete for power, money, and prestige. According to the third approach, men and women are not essentially the same. Men and women demonstrate fundamentally different worldviews due to differences in their experience, needs, competencies and values. (Yadav \& Unni, 2016). The existence of market failures that contribute to gender discrimination in the field of entrepreneurship, the predominance of men over women in this area indicates the existence of gender inequality in a fairly serious amount, which in turn requires serious practical measures in this direction (OECD, 2004).

The initial basis for the development of male and female entrepreneurship in the most general terms is one. This is economic freedom, a competitive environment, the presence of a legal framework governing entrepreneurial activity. At the same time, women and men entrepreneurs differ in their personal and business profiles: they start and manage enterprises in different sectors, develop different products, pursue different goals and structure their business in a different way (Verheul, van Stel, \& Thurik, 2006). This is largely determined by their personality and social roles. Thus, theory of social roles emphasizes the significance of such factors as cultural norms, gender stereotypes and gender roles. The theory of social construction emphasizes individual differences and suggests that they are larger than gender differences (Pines, Lerner, \& Schwartz, 2010).

Consideration of women's entrepreneurship is also possible within the framework of the biological theory of entrepreneurship, which offers explanations based on deeply rooted cultural or even biological differences between men and women. For instance, risk is a major factor in entrepreneurial activity. Moreover, when making business decisions, women prefer lower risks than men, especially in financial matters. Accordingly, they are less likely to engage in high-risk activities (Bula, 2012). Institutional theory will determine the "hidden" institutional constraints: labor market institutions, the female roles that society ascribes to, and the difficulties women entrepreneurs face when entering into entrepreneurial activity and developing their business (De Bruin, Brush, \& Welter, 2007).

Thereby, emerging literature suggests that women can 
play a significant role in the broader phenomenon of entrepreneurship and economic development (Sarfaraz, Faghih, \& Majd, 2014). In the result, there is a necessity in the study of different aspects of women entrepreneurship activity. Literature review has shown that there are different theories and concepts of entrepreneurship on women entrepreneurship. However, there has not been an agreement of opinion regarding the need for a separate theory of female entrepreneurship.

Literature review showed that the following features characterize the problems of female entrepreneurship:

a) the lack of development of theoretical aspects, the absence of not only generally accepted, but also the author's definitions of the basic concept;

b) the lack of summarizing works, the presence of only a few production articles;

c) the orientation of existing publications only on the description of business and professional status, on the analysis of business employment and the volume of entrepreneurial activity, interaction with negative practices and the evolution of the entrepreneurial elite, and a comparative description of foreign experience of women in business.

All considered models for carrying out this study, guidelines of the institutional concept of $5 \mathrm{Ms}$ were taken as a basis.

\section{Research Methods}

Women entrepreneurship research uses a variety of approaches. Therefore, scientific research differs according to generalization and system analysis of the existing methods (Kireyeva, 2016). We used research unit (individual, at the firm level), the countries covered (one country, several countries), the selected characteristics of the sample (type and size of the sample), the source and method of data (primary, secondary) used analytical methods (quantitative, qualitative, mixed) (De Bruin et al., 2007; Bula, 2012; Vial \& Richomme-Huet, 2017).

This study was conducted based on a systematic approach. The main limitation was the lack of some gender-related indicators on the issue of entrepreneurship development (for example, data on large business, output, including data by sex, age, region, industry, and also by socially vulnerable segments of the population: orphans, former prisoners, housewives, youth, retirees, people with disabilities, etc.), as well as the lag of existing indicators for 1-2 years. As a result, the research methodology was based on economic and statistical analysis of the available data.

The information base of this study was the statistics data of the Committee on Statistics of the Ministry of National
Economy of the Republic of Kazakhstan, analytical reports of the National Chamber of Entrepreneurs of the Republic of Kazakhstan, the World Bank, the International Labor Organization, the Organization for Economic Cooperation and Development, and the United Nations. The study examined the change in the level of women's entrepreneurial activity in Kazakhstan for the period from 2010 until 2018. Sections 4.2 and 4.3 compare statistics for January 1, 2017 and January 1, 2018.

Accordingly, the methodological tools proposed by the authors (determining the scale and level of development of female entrepreneurship) are performed by algorithm, which consists of four stages:

First stage - Evaluation of female entrepreneurship scale in Kazakhstan;

Second stage - Analysis of female entrepreneurship direction in Kazakhstan;

Third stage - Analysis of employment in women's enterprises;

Fourth stage - Analysis of the business environment of Kazakhstan: 5Ms of women entrepreneurship.

Theoretical and methodological background of the study of business environment in Kazakhstan was the main provision of the concept of 5Ms. This is an extended version of the $3 \mathrm{Ms}$ institutional theory, according to which the launch and development of an enterprise requires three important factors: market, money and management. For further gender mainstreaming "motherhood" and "meso / macro environment" factors are added to the existing three factors. The inclusion of the "motherhood" factor indicates that the home / family context affects the woman more than the man, which reinforces the importance of addressing issues of gender discrimination in business: ownership, access to resources, and the possibility of realizing one's potential.

The central "maternal" aspect influences other factors: money for women's entrepreneurship, women's management and market opportunities for women, mesoand macro environment for the development of women's entrepreneurship. The factors of the "macro environment" and "meso environment" reflect the influence of society's expectations and cultural norms on women's entrepreneurship. At the same time, the macro environment includes national policies, strategies, cultural, legal and economic impacts, while the meso environment reflects the influence of regional entrepreneurship support policies, development institutions, business associations, professional networks, services and initiatives (Brush, De Bruin, \& Welter, 2009; Salman \& Jamil, 2017; Zerwas, 2019). Thus, the algorithm proposed by the authors has a four-stage gradation, which should be regarded as a set of assessment indicators that determine the level of development of women entrepreneurship in Kazakhstan. 


\section{Results}

\subsection{Evaluation of the Scale of Female Entrepreneurship in Kazakhstan}

According to the data of Global Entrepreneurship Monitor in 2017, 11.3\% of women, aged 18-64 in Kazakhstan were in the process of developing of their business or have started it recently (GERA, 2018). During the period from 2010 to 2017 the percentage of enterprises, managed by women in Kazakhstan has increased from 26,1\% to $27,4 \%$ including in the context of dimension of enterprises (Figure 1). However, women representation in large business is rather low. Today there are registered 1 540592 small and medium sized enterprises in Kazakhstan, of which 1,545,994 are active, i.e. 74,4\% (Figure 1).

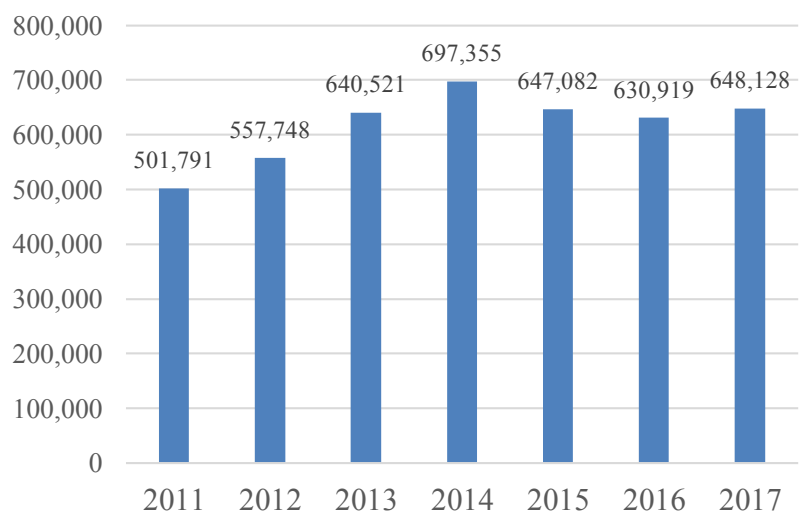

Figure 1: Number of registered enterprises headed by women, 2011-2017

Among existing 492,166 SMEs, which is $42,5 \%$ of the total are managed by women. In contrast with the same period of the last year the number of operating enterprises, managed run by women has decreased for $4,1 \%$. However, structurally the situation has not changed: in 2017 the number of operation enterprises of SMEs, run by women made up $43,25 \%$. The majority of enterprises lead by women are in Almaty city, former South Kazakhstan, current Turkestan and Almaty regions. While in the North Kazakhstan, West Kazakhstan and Kyzylorda regions, there is low entrepreneurial activity among women.

\subsection{Analysis of Directions of Entrepreneurial Activity of Women in Kazakhstan}

Researchers emphasize that in Kazakhstan the share of women in high-tech enterprises is $52,1 \%$ and $49,1 \%$ - in low-tech (Zbierowski, 2017). Among operating enterprises managed by women, the majority of enterprises involved with wholesale and retail distribution (incl. auto and motor bike service) - 232405 units (in 2017 - 257667 units), providing other types of service - 65165 units (in 2017 68733 units), agricultural sector, forestry and fish farms 48755 units (in 2017 - 44448 units), real estate operations - 47209 units (in 2017 - 42296 units). In total only 23 enterprises out of 76, which are in public administration and defense, compulsory social security, are managed by women

Over half of Kazakhstani small and medium-sized enterprises related to education; real estate operations; accommodation and food services; Wholesale and retail trade, car and motorcycle repair, healthcare and social services are headed by women. The smallest female SMEs are in areas such as mining and quarrying; electricity, gas, steam and air conditioning; construction; construction; transport and storage; agriculture, forestry and fisheries; water supply; sewer system, control over the collection and distribution of waste. Compared with a year earlier, the situation in the distribution of women's enterprises by type of economic activity is not observed (see Table 1).

Table 1: The share of small and medium-sized enterprises headed by women in Kazakhstan by type of economic activity, 2017$2018, \%$

\begin{tabular}{|c|c|c|}
\hline Activity category & $\mathbf{2 0 1 7}$ & $\mathbf{2 0 1 8}$ \\
\hline Agricultural sector, forestry and fish farms & 20,80 & 21,94 \\
\hline Industry & 31,21 & 30,70 \\
\hline Mining and quarrying & 12,17 & 12,19 \\
\hline Manufacturing industry & 32,71 & 32,83 \\
\hline Construction & 17,63 & 18,63 \\
\hline Wholesale and retail trade; car and \\
motorcycle repair & 58,38 & 56,93 \\
\hline Transport and storage & 14,42 & 16,02 \\
\hline Accommodation and food services & 61,33 & 60,46 \\
\hline Information and Communication & 31,70 & 30,84 \\
\hline Financial and insurance & 42,45 & 42,57 \\
\hline Real estate operations & 59,52 & 61,14 \\
\hline Professional, scientific and technical \\
activities & 42,17 & 42,11 \\
\hline Education & 67,50 & 68,04 \\
\hline Health and social services & 53,42 & 53,29 \\
\hline Art, entertainment and leisure & 42,18 & 42,89 \\
\hline The provision of other types of services & 48,12 & 48,10 \\
\hline
\end{tabular}

There is a specialization of female business in Kazakhstan. Kazakhstan businesswomen mainly conduct entrepreneurial activities in the tertiary sector of the economy, which is not distinguished by a high level of 
profitability. It should be noted that the main share of the shadow economy of Kazakhstan falls on the "female" sectors: trade, real estate operations, transport and agriculture, which are also leaders in the share of the shadow sector within the industry itself.

\subsection{Analysis of Employment in Women's Enterprises}

During the period from 2001 to 2018 the share of women employers has increased from $0,5 \%$ to $0,8 \%$, as well as among urban population - from $0,7 \%$ to $0,9 \%$, in rural area from $0,3 \%$ to $0,8 \%$. High share of female employers is observed in North Kazakhstan $(2,3 \%)$ and in Karaganda $(1,5 \%)$ regions. In $2008,30,41 \%$ of those employed in small and medium-sized enterprises accounted for SMEs headed by women, in absolute amount - this is 969987 workplaces. In 2017, this indicator amounted to $31,38 \%$ (964,958 workplaces). In $2018,60 \%$ of those employed in small and medium-sized enterprises in the field of health and social services accounted for SMEs headed by women (see Table 2).

Table 2: Share of employees in small and medium-sized enterprises headed by women in Kazakhstan, 2017-2018

\begin{tabular}{|c|c|c|c|c|c|c|}
\hline \multirow{2}{*}{$\begin{array}{c}\text { Type } \\
\text { of activity }\end{array}$} & $\begin{array}{c}\text { Share of emp } \\
\text { loyees in SM } \\
\text { Es headed by } \\
\text { women }\end{array}$ & $\begin{array}{c}\text { The share ofe } \\
\text { mployees atS } \\
\text { ME } \\
\text { enterprise }\end{array}$ & \multicolumn{2}{|c|}{$\begin{array}{c}\text { Share of em } \\
\text { ployers at S } \\
\text { MEs headed } \\
\text { by } \\
\text { women }\end{array}$} \\
\cline { 2 - 7 } & $\mathbf{2 0 1 7}$ & $\mathbf{2 0 1 8}$ & $\mathbf{2 0 1 7}$ & $\mathbf{2 0 1 8}$ & $\mathbf{2 0 1 7}$ & $\mathbf{2 0 1 8}$ \\
\hline $\begin{array}{c}\text { Agricultural sec } \\
\text { tor, forestry and } \\
\text { fish farms }\end{array}$ & 17,37 & 16,64 & 1,9 & 1,9 & 1,6 & 1,4 \\
\hline Industry & 17,42 & 17,00 & 7,3 & 7,6 & 4,1 & 4,2 \\
\hline $\begin{array}{c}\text { Mining and } \\
\text { quarrying }\end{array}$ & 5,38 & 5,13 & 12,1 & 12,1 & 5,4 & 5,1 \\
\hline $\begin{array}{c}\text { Manufacturing } \\
\text { industry }\end{array}$ & 20,46 & 20,01 & 6,3 & 6,9 & 3,9 & 4,2 \\
\hline Construction & 15,59 & 14,98 & 5,2 & 5,5 & 4,6 & 4,4 \\
\hline $\begin{array}{c}\text { Wholesale and } \\
\text { retail trade; car } \\
\text { and motorcycle } \\
\text { repair }\end{array}$ & 44,94 & 44,31 & 2,1 & 2,3 & 1,6 & 1,8 \\
\hline $\begin{array}{c}\text { Transport and } \\
\text { storage }\end{array}$ & 16,44 & 16,18 & 2,3 & 2,6 & 2,6 & 2,6 \\
\hline $\begin{array}{c}\text { Accommodatio } \\
\text { n and food } \\
\text { services }\end{array}$ & 40,53 & 36,83 & 3,8 & 4,2 & 2,5 & 2,6 \\
\hline $\begin{array}{c}\text { Information and } \\
\text { Communication }\end{array}$ & 27,85 & 27,05 & 3,4 & 3,5 & 3,0 & 3,1 \\
\hline $\begin{array}{c}\text { Financial and } \\
\text { insurance }\end{array}$ & 43,94 & 44,38 & 3,4 & 3,6 & 3,5 & 3,7 \\
\hline
\end{tabular}

\begin{tabular}{|c|c|c|c|c|c|c|}
\hline $\begin{array}{c}\text { Real estate } \\
\text { operations }\end{array}$ & 37,34 & 37,44 & 2,4 & 2,3 & 1,5 & 1,4 \\
\hline $\begin{array}{c}\text { Professional, } \\
\text { scientific and } \\
\text { technical } \\
\text { activities }\end{array}$ & 31,38 & 29,86 & 4,1 & 4,3 & 3,0 & 3,0 \\
\hline Education & 38,26 & 38,12 & 5,7 & 6,0 & 3,2 & 3,4 \\
\hline $\begin{array}{c}\text { Health and } \\
\text { social services }\end{array}$ & 64,70 & 60,01 & 6,9 & 7,3 & 8,3 & 8,3 \\
\hline $\begin{array}{c}\text { Art, } \\
\text { entertainment } \\
\text { and leisure }\end{array}$ & 9,17 & 9,35 & 6,0 & 5,9 & 1,3 & 1,3 \\
\hline $\begin{array}{c}\text { The provision } \\
\text { of other types of } \\
\text { services }\end{array}$ & 40,88 & 38,60 & 1,6 & 1,7 & 1,3 & 1,4 \\
\hline
\end{tabular}

As it is shown in the table, on average, fewer workers are employed at women enterprises than the national average. As it is shown in the table, on average, fewer workers are employed at women's enterprises than the national average. Therefore, in such fields as art, entertainment and recreation; water supply; sewer system, control over the collection and distribution of waste; mining and quarrying, the average number of employees at an SME in the country exceeds the level of women by more than two times. Similar excess of this indicator, but by a smaller amount, is observed in other sectors, with the exception of such areas as financial and insurance activities, transportation and warehousing, where the indicators are the same. Provided analysis of entrepreneurial activity of women in Kazakhstan indicates the need for the qualitative development of female entrepreneurship in the country namely, changing the vector of "specialization" of female business with a focus on large and highly profitable business, ensuring the entry of a businessperson in the primary and secondary sectors of the economy. This approach requires expanding of economic opportunities for women in Kazakhstan in entrepreneurship.

\subsection{Kazakhstan Business Environment Analysis: 5Ms of Female Entrepreneurship}

In 2018, Kazakhstan was ranked 64th among 137 countries in the global entrepreneurship index $(\mathrm{GEI}=29.7)$, however it lost 2 positions compared to previous year when GEI $=30$. According to this index, the strongest component of the entrepreneurial ecosystem of Kazakhstan is human capital, the weakest are technology development and risk taking.

Macro Environment. Today Kazakhstan is pursuing an active policy on ensuring gender equality, including in 
business. In 1997 there was issued the Decree of the President of the Republic of Kazakhstan "On the development of entrepreneurship among women". In 2000 there was issued the Decree of the Republic of Kazakhstan "On measures to support women's entrepreneurship". In 2006, the Strategy of Gender Equality in the Republic of Kazakhstan for 2006 - 2016 was adopted. Numerous government programs have been developed to promote women's economic empowerment, such as the 2020 Business Roadmap, 2020 Employment Roadmap, Women's Entrepreneurship Development Program for 2009-2015, Women's Entrepreneurship Micro crediting Program for 2009-2015. This trend is maintained in the Concept of Family and Gender Policy in the Republic of Kazakhstan until 2030, according to which the government committed to expand the participation of women in sectors of the economy traditionally occupied by men and in new sectors (for example, information technology, communications, tourism, entertainment).

In Kazakhstan, there are various institutions for the development of entrepreneurship, including women. One of them is Damu Entrepreneurship Development Fund JSC. The goal of this national development institute is to promote the quality development of private enterprise in the Republic of Kazakhstan by providing financial support. The services and products for entrepreneurs include financing under business lending programs through second-tier banks, microfinance organizations and leasing guarantees for business loans to second-tier banks, as well as consulting support and dissemination of information and analytical materials. The foundation is represented in all regions of Kazakhstan in 204 cities and regions of Kazakhstan.

Mezo Environment. Involvement of women leaders in the activities of associations of professional organizations makes a big difference in strengthening of women entrepreneurship, which is carried through wide dissemination among women of information on their activities in order to develop institutional infrastructure the development of informational support of female entrepreneurship is of a high importance, which is creation of specialized information center of personnel reserve based on free provision of public information on the lists of women entrepreneurs and gender-specific business practices

Non-governmental organizations take on the role of intermediaries between citizens and the state, undertake many of the functions of social transformation and work in society, make a very significant contribution to solving various problems to increase the role of women in society. In Kazakhstan, there are various organizations that promote the development of women entrepreneurship in the country: the Association of Business Women of Kazakhstan, the Union of Women Entrepreneurs of Kazakhstan, the Association of Women of Kazakhstan "Moldir", the Feminist League, the Federation of Women "Status", the Women's Leadership Fund, the Republican Council of Women, the Women's Association development and adaptation, Business Association of Women Entrepreneurs "ASIA", etc.

Money Policy. The development of female entrepreneurship through the provision of wide access to financial resources takes place within the framework of the Unified Business Support and Development Program "Employment Roadmap 2020", as well as through various programs of development institutions and international financial institutions. Since 2010, as part of a micro crediting program for women entrepreneurship, "Damu Entrepreneurship Development Fund" JSC has been involved in the conditional placement of financial resources in partner banks. Under this program, Kazakhstani businesswomen can apply to these credit organizations to receive microloans on favorable terms.

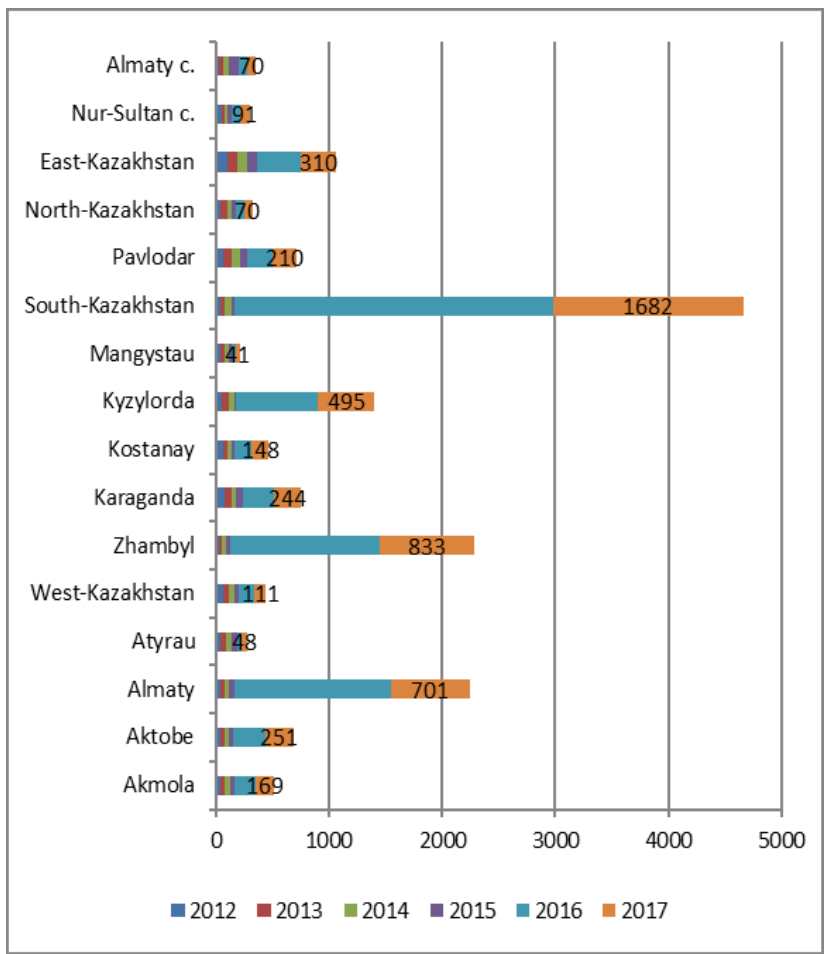

Figure 2: The number of loans issued to women entrepreneurs under the conditional placement programs, Kazakhstan, 20122017, units

During the period from 2012 to 2017, 16642 loans were issued in the total amount of 126,978 billion KZT. For the period under review, $63,6 \%$ of all loans fell to the subjects 
of female entrepreneurship in the South-Kazakhstan, Zhambyl, Kyzylorda and Almaty regions, the total amount of which amounted to 26,425 billion KZT (Figure 2).

Among the priority areas for the development of women's entrepreneurship in the rural sector are the procurement, processing and storage of agricultural products, provision of veterinary services, as well as the production of clothing, knitwear, services and more. In 2017, subsidiaries of KazAgro National Management Holding JSC issued 4652 loans totaling 31,02 billion KZT (see Table 3).

Table 3: Credits issued to women entrepreneurs, subsidiaries of KazAgro National Management Holding JSC in 2017, million KZT

\begin{tabular}{|c|c|c|c|}
\hline $\begin{array}{c}\text { Region of } \\
\text { Kazakhstan }\end{array}$ & $\begin{array}{c}\text { JSC } \\
\text { "KazAgroFi } \\
\text { nance" }\end{array}$ & $\begin{array}{c}\text { JSC “Fund for } \\
\text { financial } \\
\text { support of } \\
\text { agriculture" }\end{array}$ & $\begin{array}{c}\text { JSC Agrarian } \\
\text { Credit } \\
\text { Corporation }\end{array}$ \\
\hline Akmola & 887,0 & 15562,0 & 10619,6 \\
\hline Aktobe & 27,2 & 623,0 & 809,8 \\
\hline Almaty & 100,8 & 1483,0 & 819,7 \\
\hline Atyrau & 24,0 & 1746,0 & 945,0 \\
\hline $\begin{array}{c}\text { West- } \\
\text { Kazakhstan }\end{array}$ & 98,6 & 602,0 & 1600,9 \\
\hline Zhambyl & 14,9 & 1142,0 & 357,7 \\
\hline Karaganda & 244,9 & 1989,0 & 256,0 \\
\hline Kostanay & 187,6 & 1587,0 & 379,0 \\
\hline Kyzylorda & - & 727,0 & 237,0 \\
\hline Mangystau & 486,0 & 1656,0 & 998,0 \\
\hline $\begin{array}{c}\text { South- } \\
\text { Kazakhstan }\end{array}$ & 37,8 & 224,0 & - \\
\hline Pavlodar & 40,7 & 1558,0 & 2589,6 \\
\hline $\begin{array}{c}\text { North- } \\
\text { Kazakhstan }\end{array}$ & 61,4 & 625,0 & 273,7 \\
\hline $\begin{array}{c}\text { East- } \\
\text { Kazakhstan }\end{array}$ & 353,3 & 882,0 & 571,5 \\
\hline Nur-Sultan c. & - & 719,0 & 781,4 \\
\hline Almaty c. & 2276,3 & - & - \\
\hline
\end{tabular}

In the framework of the "Business Roadmap 2020" program, 1,021 projects were subsidized in 2017, of which 349 are related to female entrepreneurship entities. Over the entire period of the implementation of this program, 9920 projects were subsidized, of which 3043, representing $30,6 \%$ of the total number of projects, belong to women entrepreneurs. Partial guarantee of loans was received by 3103 projects, of which 1081 projects relate to the subjects of female entrepreneurship. In 2017, 506 project received partial guarantee of loans, 155 of them are "female" projects. By industry, the largest number of loans were issued for projects in the areas of trade, manufacturing, transportation and warehousing, and the provision of services.

Motherhood. This factor is especially significant under the conditions of Kazakhstan realities. In Kazakhstan, the patriarchal system of values dominates and Muslim traditions are strong. Kazakhstani society is inclined to traditional image of women and men roles with a rigid distribution of responsibilities in families. Thereat, Kazakhstani women face a double burden of work due to domestic duties and employment in the workplace or doing business. Early marriages among girls are openly undisguised in Kazakhstan, cases of bride kidnapping are extremely common, especially among ethnic groups such as Kazakhs, Kyrgyz, Kurds, Turks and Azerbaijanis. An attempt to find a good balance between work and home is a limiting factor for expanding the scale of the enterprise by the insignificant "age" of women-headed enterprises. Low turnover and small number of employees in female business show a high share of small enterprises - a consequence of the fact that women entrepreneurs are mainly concentrated in industries which does not pretend to be large in number of employees and the fact that they are more focused on controlling their time than on profit growth.

Management. It was previously noted that one of the barriers to the development of women entrepreneurship is either a low level of knowledge on management theory and practice, or their absence. It is very common that small women enterprises do not use strategic management. Given that there is a positive relationship between strategic planning and company performance efficacy, Kazakhstani women entrepreneurs are offered the services of business consultants. In the framework of the "Business Roadmap 2020 " program service support was provided to 118.7 thousand women entrepreneurs, within the framework of which specialized business services were provided free of charge to support business processes, to teach business fundamentals and professional development. The implementation of the Business Advisor Program was launched by "Damu" Foundation, in the framework of which two-day training courses for the population with entrepreneurial initiative and existing entrepreneurs were organized and conducted. In 2009, 11,603 people were trained, where women made up $60 \%$. In 2012, as part of a project to support start-up entrepreneurs (start-up projects), 10,002 women were trained, which is $58.3 \%$ of all audience. Thus, it can be concluded that Kazakhstan has a rather different level of security of $5 \mathrm{Ms}$ factors for women's business, which ultimately leads to an unstable 
model of women's entrepreneurship in the country and a slow pace of its qualitative development.

\section{Conclusions}

In general, the analysis of women entrepreneurship in Kazakhstan has led to the following conclusions. Firstly, lack of theoretical content on women entrepreneurship in Kazakhstani studies suggests that to this date there are currently no platforms for discussing the theoretical problems of women entrepreneurship in the country. At the same time there is a small number of studies on business environment of businesswomen, including special factors related to doing business in regions (for example, villages and cities) and business area (for example, industry and service). While as study of female entrepreneurship is possible in the context of the influence of such factors as legislation, social norms, economic policy, the structure of the labor market, income and education levels.

Secondly, in Kazakhstan, there appears growth of women's contribution to the socio-economic development of the republic. There is increase in entrepreneurship activity among women, increase in the number of enterprises headed by them. However, the growth of women's enterprises occurs while maintaining the insignificance of their size in terms of turnover and number of employees. Thus, Kazakhstani women are most represented in the sector of small and medium-sized businesses. In the northern and eastern regions of the country, there is a high percentage of enterprises headed by women, in the south - low. At the same time, the situation with large and medium-sized enterprises is opposite. Women entrepreneurs of Kazakhstan provide a third of jobs in the SME sector of the republic. There is a prominent industry characteristic of women entrepreneurship. Women's business is concentrated mainly in the service sector. The sectors where female enterprises now predominate are mainly related to solving social problems that a woman often encounters when conducting her household life; they do not require technical education, a large number of employees and large capital. The ethno cultural specificity of Kazakhstani society also leaves its mark on the development of women's business; women have been entrusted with the need for housekeeping and taking care of family members.

Thirdly, today women have variety of economic opportunities for self-realization in entrepreneurial activity. At the same time, there is low level of gender discrimination when considering social institutions. The results of the Global Monitoring of Entrepreneurship confirm that in Kazakhstan there is a new wave of female entrepreneurship, where women are engaged in entrepreneurial activities by virtue of realizing their potential and finding new opportunities. At the same time, the first wave of female entrepreneurship occurred during the collapse of the Soviet Union and the declaration of independence of Kazakhstan, when the people faced many political and socio-economic problems. Due to the unemployment, the need and necessity to provide for their families, women took up small business and the development of their subsidiary plots. It was then that women shuttles appeared who stood at the origins of female entrepreneurship in the country.

Fourthly, Kazakhstan has a rather different level of security for $5 \mathrm{Ms}$ factors for women's business, in particular, a high level of development of the macro- and mesoinfrastructure factor, medium - money and management, low - market and money. This leads to the instability of the model of women entrepreneurship in the country and the slow pace of its qualitative development.

Fifthly, the analysis of environmental factors and internal characteristics of female entrepreneurship in Kazakhstan allows us to justify the set of strategic actions for its development: export support for women entrepreneurs; development of the high-tech sector of women's business; development of a system of social support for motherhood; development of business education among girls; development of infrastructure to support women's entrepreneurship; development of a system of indicators for monitoring and development of women's entrepreneurship. The proposed set of strategic actions requires priority attention. The selected strategies do not negate the importance of moving forward in other areas.

The scientific results obtained during the study may be subjective. However, due to the lack of methodological and statistical basis for quality monitoring, analysis, evaluation and forecasting of the development of female entrepreneurship, they can be taken into account to determine the status and priority directions of its development.

\section{References}

Ács, Z. J., Szerb, L., \& Lloyd, A. (2017). The Global Entrepreneurship Index 2018. Washington, DC: The Global Entrepreneurship and Development Institute.

Adachi, T., \& Hisada, T. (2017). Gender Differences in Entrepreneurship and Intrapreneurship: an Empirical Analysis. Small Business Economics, 48(3), 447-486.

ADB (2013). Kazakhstan Country Gender Assessment. Mandaluyong: Asian Development Bank.

Aidis, R., \& Weeks, J. (2016). Mapping the Gendered Ecosystem: The Evolution of Measurement Tools for Comparative High- 
Impact Female Entrepreneur Development. International Journal of Gender and Entrepreneurship, 8(4), 330-352.

Andriuta, X., Kartašova, J. (2013). Female Entrepreneurship Patterns: a Theoretical Comparative Study. Verslo Sistemos ir Ekonomika (Business Systems and Economics), 3(2), 187-195.

Brush, C. G., De Bruin, A., \& Welter, F. (2009). A Gender Aware Framework for Women's Entrepreneurship. International Journal of Gender and Entrepreneurship, 1(1), 8-24.

Bula, H. O. (2012) Evolution and Theories of Entrepreneurship: a Critical Review on the Kenyan perspective. International Journal of Business and Commerce, 1(11), 81-96.

Carlsson, B., Braunerhjelm, P., McKelvey, M., Olofsson, C., Persson, L., \& Ylinenpaa, H. (2013). The Evolving Domain of Entrepreneurship Research. Small Business Economics, 41(4), 913-930.

Chandrashekhar G. R. (2011). Female Entrepreneurship in East and South East Asia: Opportunities and challenges. Asian Business \& Management, 3(10), 461-462.

De Bruin, A., Brush, C. G., \& Welter, F. (2007). Advancing a Framework for Coherent Research on Women's Entrepreneurship. Entrepreneurship Theory and Practice, 31(3), 323-339.

Dos Santos, V. F., Morais, G. M., De Araújo Ribeiro, F. F., \& Pardini, D. J. (2019). Female Entrepreneurship: Evolution, Current Challenges, and Future Prospects. International Journal of Business Administration, 10(5), 24-32.

Ebner, A. (2005). Entrepreneurship and Economic Development. From Classical Political Economy to Economic Sociology. Journal of Economic Studies, 32(3), 256-274.

Estrin, S., \& Mickiewicz, T. (2011). Institutions and female entrepreneurship. Small Business Economics, 37(4), 397-415.

Fayolle, A., \& Kyrö, P. (2008). The Dynamics between Entrepreneurship, Environment and Education. Cheltenham, England: Edward Elgar Publishing Limited.

GERA (2018). Global Entrepreneurship Monitor: Global Report 2017/18. London, UK: Global Entrepreneurship Research Association (GERA).

Gupta, V. K., Dutta, D. K., Guo, G., Javadian, G., Jiang, C., Osorio, A. E., \& Ozkazanc-Pan, B. (2016). Classics in Entrepreneurship Research: Enduring Insights, Future Promises. New England Journal of Entrepreneurship, 19(1), 7-22.

Gupta, S., Pingali, P. L., \& Pinstrup-Andersen, P. (2017). Women's Empowerment in Indian Agriculture: Does Market Orientation of Farming Systems Matter? Food Security: The Science, Sociology and Economics of Food Production and Access to Food, 9(6), 1447-1463. DOI: 10.1007/s12571-0170737-4

Jennings, J. E., \& Brush, C. G. (2013). Research on Women Entrepreneurs: Challenges to (and from) the Broader Entrepreneurship Literature? Academy of Management Annals, 7, 661-713.

Kim, I. E., \& Yang, H. C. (2020). The Effects of Perceived Satisfaction Level of High-Involvement Product Choice Attribute of Millennial Generation on Repurchase Intention: Moderating Effect of Gender Difference. Journal of Asian Finance, Economics and Business, 7(1), 131-140. https://doi.org/10.13106/jafeb.2020.vol7.no1.131

Kireyeva, A. A. (2016). The Formation of Information
Technology Clusters in Kazakhstan: System and Structured Approaches. Journal of Asian Finance, Economics and Business, $\quad 3(2), \quad 51-57$. https://doi.org/10.13106/jafeb.2016.vol3.no2.51.

Kireyeva, A. A., Abilkayir, N. A. \& Tsoy, A. A. (2018). A Study on the Distribution of Information and High Technology Clusters: Kazakhstan's Experience. Journal Distribution of Science, 16(4), 5-15. DOI: 10.15722/jds.16.4.201804.5

Kireyeva, A. A., \& Satybaldin, A. A. (2019). Analysis of Gender Pay Gap in Different Sectors of the Economy in Kazakhstan. Journal of Asian Finance, Economics and Business, 6(2), 231-238. https://doi.org/10.13106/jafeb.2019.vol6.no2.231.

OECD (2004). Women's Entrepreneurship: Issues and Policies. Paris, France: OECD Publishing.

OECD (2014). Society at a Glance: Asia/Pacific 2014. Paris, France: OECD Publishing.

Okafor, C., \& Amalu, R. (2010). Entrepreneurial Motivations as Determinants of Women Entrepreneurship Challenges. Petroleum-Gas University of Ploiesti Bulletin. Economic Sciences Series, 62(2), 67-77.

Parker, B. J. (2010) A Conceptual Framework for Developing the Female Entrepreneurship Literature. Journal of Research on Women and Gender, 1(21), 169-190.

Pines, A. M., Lerner, M., \& Schwartz, D. (2010) Gender Differences in Entrepreneurship: Equality, Diversity and Inclusion in Times of Global Crisis. Equality, Diversity and Inclusion: An International Journal, 29(2), 186-198.

Poggesi, S., de Vita, L., \& Mari, M. (2015). What's New in Female Entrepreneurship Research? Answers from the Literature. International Entrepreneurship and Management Journal, 12(6), 735-764.

Salman, A., \& Jamil, S. (2017). Entrepreneurial Finance and its Impact on e-Business. Problems and Perspectives in Management, 15(3), 24-41.

Sarfaraz, L., Faghih, N., \& Majd, A.A. (2014). The Relationship between Women Entrepreneurship and Gender Equality. Journal of Global Entrepreneurship Research, 2(1), 1-11.

Sospeter, N. G., Rwelamila, P. D., Nchimbi, M., \& Masoud, M. (2014). Review of Theory and Practice Literature on Women Entrepreneurship in the Tanzanian Construction Industry: Establishing the Missing Link. Journal of Construction in Developing Countries, 19(2), 75-85.

Verheul, I., van Stel, A., \& Thurik, R. (2006). Explaining Female and Male Entrepreneurship at the Country Level. Entrepreneurship \& Regional Development, 18(2), 151-183.

Vial, V., \& Richomme-Huet, K. (2017). Women Entrepreneurs in France. International Journal of Entrepreneurship and Small Business, 30(1), 80-109.

Xie, X., \& Lv, J. (2018) Female Technology Entrepreneurs: Resource Shortages and Reputation Challenges - a View of Institutional Support. International Entrepreneurship and Management Journal, 14(2), 379-403. DOI: 10.1007/s11365017-0450-y

Yadav, V., \& Unni, J. (2016). Women entrepreneurship: research review and future directions. Journal of Global Entrepreneurship Research, 6(12), 1-18.

Yordanova, D. I., \& Tarrazon, M.-A. (2010). Gender differences in entrepreneurial intentions: evidence from Bulgaria. Journal of Developmental Entrepreneurship, 15(3), 245-261. 
Zbierowski, P. (2017). The Aspirations of New Technology-Based Firms in CEE and CIS Countries? Foresight and STI Governance, 11(3), 50-60.
Zerwas C. S. (2019). Work-Life Balance and Women's Entrepreneurship: An Exploration of Influencing factors. Cham, Switzerland: Springer Nature Switzerland AG. 